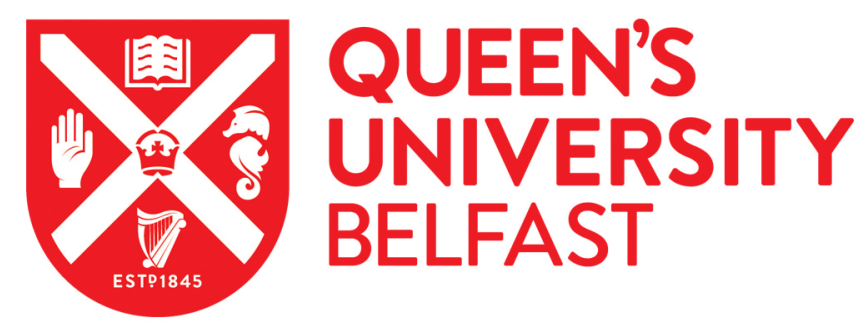

\title{
Treatment and Outcomes of Children with Febrile Urinary Tract Infection due to Extended Spectrum Beta-lactamase-producing Bacteria in Europe: TOO CUTE Study
}

Vazouras, K., Hsia, Y., Folgori, L., Bielicki, J., Aguadisch, E., Bamford, A., Brett, A., Caseris, M., Cerkauskiene, R., De Luca, M., losifidis, E., Kopsidas, J., Manzanares, Á., Planche, T., Riordan, A., Srovin, T. P., Valdivielso Martínez, A. I., Vergadi, E., Sharland, M., \& Basmaci, R. (2020). Treatment and Outcomes of Children with Febrile Urinary Tract Infection due to Extended Spectrum Beta-lactamase-producing Bacteria in Europe: TOO CUTE Study. The Pediatric Infectious Disease Journal. https://doi.org/10.1097/INF.0000000000002838

Published in:

The Pediatric Infectious Disease Journal

Document Version:

Peer reviewed version

Queen's University Belfast - Research Portal:

Link to publication record in Queen's University Belfast Research Portal

Publisher rights

Copyright 2020 Lippincott, Williams \& Wilkins. This work is made available online in accordance with the publisher's policies. Please refer to any applicable terms of use of the publisher.

\footnotetext{
General rights

Copyright for the publications made accessible via the Queen's University Belfast Research Portal is retained by the author(s) and / or other copyright owners and it is a condition of accessing these publications that users recognise and abide by the legal requirements associated with these rights.
}

Take down policy

The Research Portal is Queen's institutional repository that provides access to Queen's research output. Every effort has been made to ensure that content in the Research Portal does not infringe any person's rights, or applicable UK laws. If you discover content in the Research Portal that you believe breaches copyright or violates any law, please contact openaccess@qub.ac.uk. 
Treatment and Outcomes of Children with Febrile Urinary Tract Infection due to Extended Spectrum Beta-lactamase-producing Bacteria in Europe: TOO CUTE Study

Konstantinos Vazouras, MD, MPH $(1,2)^{*}$, Yingfen Hsia, PhD (1,3), Laura Folgori, MD (1,4), Julia Bielicki, MD (1,5), Elise Aguadisch, MD (6), Alasdair Bamford, MD, PhD

(7), Ana Brett, MD, MSc (8), Marion Caseris, MD (9), Rimante Cerkauskiene, MD, PhD

(10), Maia De Luca, MD (11),Elias Iosifidis, MD, MSc, PhD (12), John Kopsidas, MD

(2), Ángela Manzanares, MD (13), Tim Planche, MD (14), Andrew Riordan, MD,

FRCPCH (15), Tina Plankar Srovin, MD, PhD (16), Ana Isabel Valdivielso Martínez,

MD (17), Eleni Vergadi, MD, MSc, PhD (18), Mike Sharland, MD (1), and Romain

Basmaci, $\mathrm{MD}, \mathrm{PhD}(6,19)$

Corresponding Author: Konstantinos Vazouras

Address: Collaborative Center of Clinical epidemiology and Outcomes Research

5, Chatzigianni Mexi, Post Code 11528, Athens

Tel: +306981031132

E-mail: k.vazouras@cleoresearch.org

Abbreviated title: ESBL Febrile Urinary UTIs in Children: Treatment and Outcomes

Running Head: TOO CUTE Study

1. Paediatric Infectious Diseases Research Group, Institute for Infection and Immunity, St George's University of London, London, United Kingdom

2. Stavros Niarchos Foundation-Collaborative Center for Clinical Epidemiology and Outcomes Research and Division of Infectious Diseases (CLEO), Athens, Greece 
3. School of Pharmacy, Queen's University Belfast, Belfast, UK

4. Paediatric Infectious Disease Unit, Department of Paediatrics, Luigi Sacco Hospital, University of Milan, Milan, Italy

5. Paediatric Pharmacology, University Children's Hospital Basel, Basel, Switzerland

6. Service de Pédiatrie-Urgences, Hôpital Louis-Mourier, Assistance Publique - Hôpitaux de Paris, F-92700 Colombes, France

7. Department of Paediatric Infectious Diseases, Great Ormond Street Hospital for Children NHS Trust, London

8. Serviço de Urgência e Unidade de Infecciologia, Hospital Pediátrico, Centro Hospitalar e Universitário de Coimbra, Coimbra, Portugal

9. Service pédiatrie générale, Hôpital Robert Debré, F-75019 Paris, France

10. Clinic of Paediatrics, Faculty of Medicine, Vilnius University, Vilnius, Lithuania

11. Immunology and Infectious Diseases Unit, University Hospital Pediatric Department, Bambino Gesù Children's Hospital, Rome, Italy

12. Third Department of Pediatrics, Aristotle University, Medical Faculty, School of Health Sciences, Hippokration Hospital, Thessaloniki, Greece

13. Hospital 12 de Octubre, Facultad de Medicina, Universidad Complutense, Madrid, Spain 14. Medical Microbiology Department, South West London Pathology, Jenner Wing St George's Hospital, London, UK

15. Paediatric Infectious Diseases and Immunology, Alder Hey Children's NHS Foundation Trust, Liverpool, UK

16. Department of Infectious Diseases, University Medical Centre, Ljubljana, Slovenia

17. Department of Paediatrics, Regional University Hospital of Malaga, Spain 
18. Department of Paediatrics, Heraklion University Hospital, University of Crete, Greece 19. Université de Paris, Infection, Antimicrobiens, Modélisation, Evolution, Unité Mixte de Recherche 1137, Institut National de la Santé Et de la Recherche Médicale, F-75018 Paris, France

Key Words: pyelonephritis, extended-spectrum beta lactamase, antibiotics, clinical outcomes, children 


\title{
Objective
}

The prevalence of extended-spectrum beta-lactamase producing Enterobacteriaceae (ESBLPE) is increasing globally. ESBL-PE are an important cause of urinary tract infections (UTIs) in children. We aimed to characterize the clinical presentation, treatment and outcomes of childhood UTI caused by ESBL-PE in Europe.

\section{Design}

Multi-center retrospective cohort study

\begin{abstract}
Patients and Setting
Children 0-18 years of age with fever, positive urinalysis and positive urine culture for an ESBL-PE uropathogen, seen in a participating hospital from January 2016 to July 2017.
\end{abstract}

\section{Main outcome measures}

Primary outcome measure: day of defervescence was compared between a) initial microbiologically effective treatment (IET) versus initial microbiologically ineffective treatment (IIT), b) single initial antibiotic treatment versus combined initial antibiotic treatment. Secondary outcome measures: clinical and microbiological failure of initial treatment

\section{Results}

We included 142 children from 14 hospitals in 8 countries. Sixty-one children had IET and 77 IIT. There was no statistical difference in time to defervescence for effective/ineffective groups ( $\mathrm{p}=0.722)$ and single/combination therapy groups $(\mathrm{p}=0.574)$. Two out of $59(3.4 \%)$ and 4/66 (6.1\%) patients exhibited clinical failure during treatment $(\mathrm{p}=0.683)$ when receiving IET or IIT respectively. Eight of $51(15.7 \%)$ receiving IET and 6/58 (10.3\%) receiving IIT 
patients $(\mathrm{p}=0.568)$ had recurring symptoms/signs suggestive of a UTI. Recurrence of a UTI occurred 15.5 days (IQR 9.0 - 19.0) after the end of treatment.

\section{Conclusions}

Time to defervescence and clinical failure did not differ between IET/IIT groups. Noncarbapenem beta-lactam antibiotics may be used for the empiric treatment of ESBL febrile UTIs, until susceptibility testing results become available. 


\section{INTRODUCTION}

The extended-spectrum beta-lactamase producing enterobacteria (ESBL-PE) are recognized as a serious threat by the United States Center for Disease Control and Prevention and the World Health Organization ${ }^{1,2}$. ESBL enzymes are capable of conferring bacterial resistance to commonly used antibiotics such as penicillins and cephalosporins ${ }^{3}$. Due to concern about high resistance rates to these antibiotics, carbapenems are often used as empiric therapy for severe infections caused by ESBL-PE's ${ }^{4,5}$. Several studies have reported the growing prevalence of ESBL-PE infections worldwide ${ }^{6-8}$, including children with urinary tract infection (UTI) ${ }^{6,9,10}$. A meta-analysis has shown that the estimated pooled prevalence of childhood UTIs caused by ESBL-PE was globally $14 \%{ }^{10}$, for both community acquired and healthcare acquired infections. The prevalence of childhood ESBL-PE UTIs varies across regions with the lowest rate in the Americas (2\%), $12 \%$ in Europe, 37\% in South-East Asia, and the highest rate in Africa with $76 \%{ }^{10}$. ESBL-PE UTIs are associated with longer hospital stays and higher costs in adults ${ }^{11}$. International guidelines recommend a range of empiric options for UTI treatment in children, including amoxicillin/clavulanic acid (co-amoxiclav), cotrimoxazole, ciprofloxacin or $2^{\text {nd }}$ or $3^{\text {rd }}$ generation cephalosporins ( $2 \mathrm{GC}$ or $3 \mathrm{GC}$ ) for oral and $3 \mathrm{GC}$ or aminoglycosides for intravenous treatment of febrile UTIs (fUTIs) ${ }^{12-14}$. However, ESBL-PEs often possess mechanisms which confer co-resistance to a number of the recommended first line antibiotics ${ }^{3}$. Despite international guidance, currently there are limited studies on evaluating clinical management of children with ESBL-PE UTIs. We conducted a European multicenter study to: a) characterize the clinical and microbiologic presentations of pediatric patients with ESBL-PE UTIs, b) describe treatment patterns, clinical and microbiologic outcomes.

\section{METHODS}




\section{Study design and population}

This was a multicenter, multinational, retrospective cohort study. Anonymous data were collected using a web-based electronic form in REDCap. Demographic data, diagnosis, comorbidity, medical history, antibiotic prescribing information (drug name, dose, route of administration and dosing), clinical and microbiologic outcomes were recorded.

\section{Inclusion and Exclusion Criteria}

Children 0-18 years of age were included in the study if they were seen within a hospital setting (inpatients, outpatients clinics or emergency departments) from $1^{\text {st }}$ January 2016 to $31^{\text {st }}$ July 2017. We included patients with fever $\geq 38^{\circ} \mathrm{C}$ at or prior to admission and positive urine examination. Positive urine examination was defined by the presence of both "a" and "b": a) isolation of ESBL-producing bacteria either from spontaneously voided urine / midstream cleancatch method with $\geq 10^{5}$ colony forming units (cfu) per $1 \mathrm{~mL}$ of urine OR suprapubic aspirate/urinary catheter with $\geq 10^{4} \mathrm{cfu} / \mathrm{mL}$ of urine, $\mathrm{b}$ ) either abnormal dipstick test (leucocyte esterase $>1+$, or nitrite positive) or abnormal urine microscopy (WBCs $>5$ per high-power field in centrifuged or $>10 / \mathrm{mm}^{3}$ in non-centrifuged samples). Patients were excluded from the study in the presence of any other bacterial species $\geq 10^{4} \mathrm{cfu} / \mathrm{mL}$ within the same urine sample. Patients were also excluded if they received antibiotics (other than prophylaxis) in the past 48 hours prior to clinical diagnosis or if they had another concurrent infection necessitating antibiotic treatment.

\section{Definitions}


Patients were classified into two groups according to their initial antibiotic treatment: those who received microbiologically effective and those who received microbiologically ineffective treatment. Microbiologic effectiveness was defined as in vitro susceptibility of the pathogen to at least one of the initial choices of empiric antibiotic therapy. Microbiologic ineffectiveness was defined as in vitro resistance or intermediate sensitivity of the pathogen to each of the initial antibiotic(s) prescribed ${ }^{15}$. Switched treatment was defined as antibiotics given after initial antibiotics were changed. Switched treatment could either be empiric or targeted. Early clinical failure of the initial treatment was defined as the persistence/recurrence of fever or signs/symptoms suggestive of UTI during treatment. Late clinical failure was defined as the recurrence of signs/symptoms within one month after the end of treatment. Microbiologic failure during treatment or after treatment was defined as a persistent or recurrent positive urine culture.

\author{
Main Outcome Measures \\ The primary outcome measure was to assess the day of defervescence compared between a) \\ initial microbiologically effective treatment versus initial microbiologically ineffective \\ treatment, and b) single initial antibiotic treatment versus combined initial antibiotic treatment. \\ The secondary outcome measures were clinical and microbiologic failure of the initial treatment. \\ Patients were excluded from early clinical outcomes if the assessment was done earlier than 2 \\ days after starting treatment or if the timing of clinical assessment was uncertain.
}

Statistical analysis 
We compared categorical variables with $\chi^{2}$ or Fisher's exact test and continuous variables with Mann-Whitney $U$ tests. A P value of $<0.05$ was considered significant for all tests. The analysis was performed using STATA version 14 (Stata Corp LP, College Station, TX, United States).

\section{Ethical approval}

Each site was responsible to clarify the type of permission needed to participate in the study. Ethical approvals were obtained- where needed- either from the local Research and Development Department or the Institutional Review Board /Ethics Committee.

\section{RESULTS}

There were 14 hospitals from 8 European countries (United Kingdom, 3; Greece, 3; France, 2; Spain, 2; Italy, 1; Portugal, 1; Slovenia, 1; Lithuania, 1) participating in this study (see Table, Supplemental Digital Content 1).

A total of 142 children were included (Figure 1), of which 57 (40.1\%) were males. Median age was 1.1 years (interquartile range $0.5-4.0$ ). Demographical, clinical and laboratory findings are shown in Table 1. Microbiologic effectiveness of the initial treatment was determined in 138/140 patients, as 2 patients were treated with an antibiotic not tested in the antibiogram. Early or late clinical outcomes could not be assessed in two patients (autonomic dysregulation and palliative care pathway), thus they were excluded from outcomes analysis. Baseline characteristics of "effective" (n=61) and "ineffective group" $(\mathrm{n}=77)$ were compared. Patients in the "ineffective group" were younger in age $(\mathrm{p}=0.034)$, had fewer urinary tract (UT)-related $(\mathrm{p}=0.013)$, or other comorbidities ( $\mathrm{p}<0.001)$, and lower rates of antibiotic prophylaxis $(\mathrm{p}=0.008)$ (Table 1$)$. 
The most commonly identified ESBL-PE pathogen was E. coli, 122 (85.9\%), followed by Klebsiella spp., 15 (10.6\%), Enterobacter spp. 3 (2.1\%), Pseudomonas aeruginosa 1 (0.7\%) and Morganella morganii 1 (0.7\%). ESBL screening was carried out using European Committee on Antimicrobial Susceptibility Testing (EUCAST) guidelines ${ }^{16}$ in 12/14 (85.7\%) of participating centers and in 2/14 (14.3\%) using Clinical and Laboratory Standards Institute (CLSI) guidelines ${ }^{17}$. Production of ESBL was confirmed with the combination disk synergy test in 10/14 (71.4\%) of participating centers, in 2/14 (14.3\%) using Vitek2 or in 2/14 (14.3\%) using other tests (ABCD test, 1; MicroScan WalkAway, 1). Local phenotypic resistance of E. coli and Klebsiella spp. are shown in Table 2. No molecular typing data was available at any site. Thirty different initial regimens were identified in this population (see Table, Supplemental Digital Content 2). Initial treatment was empiric for 121 (85.2\%) patients. A total of 124 (87.3\%) patients were initially prescribed a single antibiotic, while $18(12.7 \%)$ patients had a combination of two antibiotics. Seventy-six (53.5\%) patients were initially prescribed a single, noncarbapenem beta-lactam agent, mostly co-amoxiclav $(17,12.0 \%)$ or cefotaxime $(16,11.3 \%)$, while $12(8.5 \%)$ patients received a carbapenem alone. One hundred-one (71.1\%) patients had initial intravenous treatment, 40 (28.2\%) patients received only oral treatment, and $1(0.7 \%)$ a combination of oral and intravenous antibiotics. Median duration of treatment was 10 days (IQR $7.0-11.0)$

\section{Time to defervescence}

The day of defervescence was available for 99 patients. There was no statistically significant difference ( $\mathrm{p}=0.722$ ) in time to defervescence between the effective (median 1.0 days, IQR 0 2.0 days) and ineffective groups (median 1.0 days, IQR $0-2.0$ days). Subgroup analysis revealed no difference in time to defervescence between patients with effective and ineffective 
treatment regarding age-groups, sex, co-morbidities, pathogens and initial type of treatment (Table 3).

No significant difference in time to defervescence $(\mathrm{p}=0.574)$ was detected between the single therapy (median 1.0, IQR $0-2.0$ ) and combination therapy groups (median 1.0, IQR $0-2.0$ ). The two groups (single versus combined antibiotics) were similar in terms of age $(\mathrm{p}=0.055)$, sex $(\mathrm{p}=0.199)$, pathogens $(\mathrm{p}=0.285)$, UT-related $(\mathrm{p}=0.129)$ or other comorbidities $(\mathrm{p}=0.797)$, and effectiveness of treatment $(\mathrm{p}=0.183)$.

\section{Clinical Failure}

Early clinical outcome was recorded for 59/61 (96.7\%) and 66/77 (85.7\%) patients receiving an initial effective or ineffective regimen, respectively. Two patients $(3.4 \%)$ receiving initial effective treatment exhibited early clinical failure, whereas 4/66 (6.1\%) with initial ineffective therapy had early clinical failure $(\mathrm{p}=0.683)$ (Table 1$)$. No significant trends were identified in subgroup analysis among baseline characteristics between the two groups (Table 3). All characteristics and outcomes of patients treated with ineffective treatments are shown in Supplemental Digital Content (Table 3).

Fourteen $(14 / 113,12.4 \%)$ children had late clinical failure 15.5 days (IQR 9-19) after the end of treatment. Among the 16 patients whose total treatment course included only ineffective therapies (either initial or switched treatment) and had full clinical follow-up, 2/16 (12.5\%) had late clinical failure. No difference in late clinical failure $(\mathrm{p}=1.000)$ was found between patients having only microbiologically ineffective antibiotics $(2 / 16,12.5 \%)$ and those having at least one effective antibiotic $(12 / 97,12.4 \%)$ during their total course of treatment. 


\section{Microbiologic Failure}

Among 43 patients having a repeated urine culture during treatment, 12 exhibited a

microbiologic failure. A repeated urine culture was also collected after the end of treatment in 24 children. In 17/24 patients the urine culture was positive. Among these patients, 9 had the same pathogen and 8 had either a new pathogen or the same pathogen but with a different susceptibility pattern.

\section{DISCUSSION}

\section{Main Findings}

In our study, we did not observe any significant difference in time to defervescence and rates of clinical failure between patients receiving initial effective compared with ineffective treatment for ESBL UTIs. The great majority of patients (95.2\%) had an adequate clinical and microbiologic response despite receiving antibiotics to which their UTI was phenotypically resistant to in vitro.

\section{ESBL fUTIs pathogens and current treatment options}

E. coli was the most common reported pathogen in our study. This is consistent with other studies $^{15,18-20}$. We observed high resistance rates $(>50 \%)$ of E. coli to co-amoxiclav, cotrimoxazole and ciprofloxacin. Resistance rates were $10 \%$ for aminoglycosides and $50 \%$ for piperacillin-tazobactam. Resistance rates to fosfomycin, mecillinam, and temocillin were low $(<10 \%)$. The resistance rates in our study are similar to other European cohort studies ${ }^{18,21-23}$. 
Parenteral carbapenems are considered as the treatment of choice for invasive ESBL

infections $^{24,25}$. However, due to the increased need for carbapenem-sparing strategies, the use of alternative agents is important. In our study, a wide variety of oral and intravenous antibiotics were used for the initial or targeted treatment of ESBL fUTIs, such as beta-lactam/beta-lactam inhibitor combinations, cephalosporins, aminoglycosides and quinolones.

Piperacillin-tazobactam has been investigated for ESBL E.coli UTIs in adults ${ }^{19}$, while a recent multi-center study of ESBL fUTIs has shown similar clinical efficacy for children receiving amikacin or carbapenem monotherapy as initial empiric treatment ${ }^{18}$. Oral antibiotics, such as ciprofloxacin or cotrimoxazole have also been suggested for targeted treatment of ESBL fUTIs in children ${ }^{18}$. Finally, the combination of co-amoxiclav and cefixime ${ }^{26}$ and older, off patent antibiotics (pivmecillinam, temocillin and fosfomycin) have investigated as potential ESBL-PE treatment options due to their favorable in vitro activity ${ }^{21}$. It should be noted that clinicians should take into account a patient's clinical condition, type of ESBL-PE strain and MIC while treating with a carbapenem-alternative ${ }^{4}$.

\section{Outcomes and microbiologically ineffective treatments}

The results of our study are similar to a French cohort study ${ }^{18}$, where children became afebrile in 1.8 days (1.0 day in our study). The time to defervescence and length of hospital stay did not differ between effective or ineffective treatments ${ }^{18}$. In another pediatric cohort of non-resistant UTIs, no difference in fever duration was detected between effective (48 hours, IQR 24-240) and ineffective treatment groups (78 hours, IQR $48-132)^{15}$. A similar effect of ineffective initial therapy on the time to resolution of symptoms has been found in adult studies ${ }^{27}$. Inappropriate 
empirical antibiotic therapy did not adversely affect clinical and microbiologic cure rate or UTI recurrence in a Korean cohort study of adults with acute ESBL pyelonephritis ${ }^{28}$. In a multicenter study in the United States, 316 children with a UTI (63\% of which were febrile) who received initially discordant antibiotics, only $2.2 \%$ required an escalation of therapy. However, patients with complicated backgrounds were excluded from this cohort, while the median of follow-up was 3 days. In our study, although most children became afebrile within 2 days, recurrence of a UTI occurred in 14/113 (12.4\%) children 15.5 days (IQR 9.0 - 19.0) after the end of treatment ${ }^{29}$. A relapse of a UTI has been documented in 4/146 (2.7\%) within 2 weeks after treatment in another study ${ }^{30}$. The lower rate of relapse in this previous study could be due to lower rates of UT-related (29.5\%) or other comorbidities (10.3\%), or the shorter follow-up period ( 2 weeks versus 1 month $)^{30}$. In another study ${ }^{18}$, no recurrence was observed within 10 days after the end of treatment. Whether this may be due to the short follow-up period is unclear. Furthermore, this difference may also be explained by a lower comorbidity rate $(15.7 \%)$ in the French cohort than in our study (35.9\%) and the more frequent use of combined antibiotics (40.2\% versus $12.7 \%)$.

In our study, 16 patients had exclusively ineffective treatments during their treatment course. These children had identical recurrence rates after the end of treatment with those treated with at least one effective antibiotic during their course. Our multi-center study supports the findings of a previous, smaller, single-center study ${ }^{31}$. The achieved concentration of antibiotics in the urinary tract may explain these results. Most antibiotics used to treat UTIs, such as beta-lactams and aminoglycosides, are renally excreted, thus antibiotic concentrations at the site of infection are higher than can be achieved in the serum or cerebrospinal fluid ${ }^{5,32}$. 


\section{Strengths and limitations}

To our knowledge, this is the first multicenter European study to explore ESBL fUTIs treatment patterns and clinical outcomes. Our study has shown the wide variation of antibiotics used as initial treatment for ESBL fUTIs. We stratified outcomes according to the microbiologic effectiveness of initial treatment given. We observed favorable initial clinical outcomes of ineffective antibiotics against ESBL fUTIs in children, as previously shown in childhood and adult studies ${ }^{15,28}$.

However, there are a number of limitations in our study. The main limitation is the lack of any systematic sampling method, which does not allow for results to be generalized to other populations. We also need to note the potential sampling bias. Misclassification of uropathogens or coding error may have affected patient's inclusion in the study. Another limitation is the noted differences between initial "effective" and "ineffective" antibiotic groups at their baseline characteristics, namely age and comorbidities. In this context, the comparison of outcome measures between these groups has to be interpreted with caution. Furthermore, patients were included only if they were seen and followed-up within the same hospital. This may have affected the clinical failure rates if children were treated for a recurrence in another hospital or in the community. Finally, no imaging data was available for these children and any evidence of renal scarring associated with ineffective treatment could not be determined.

\section{Implications for future studies}

Our study has shown a low rate $(6.1 \%)$ of clinical failures with initial microbiologically ineffective treatment for ESBL febrile UTIs in children. As shown in the current and other studies ${ }^{18}$, most children have a clinical response regardless of the initial treatment given. As 
such, the estimated effect size between effective and ineffective groups is so low that the sample size required to power future trials would need to be very high in order to detect significant differences in outcomes ${ }^{33}$. These data suggest that further randomized trials on ESBL febrile UTIs comparing the clinical efficacy of empiric prescribing strategies may not be straightforward or, indeed, feasible as the great majority of children become afebrile in less than two days ${ }^{18}$. Unlike adults where fever is not mandatory for patient's inclusion, as fever may be absent especially in the elderly ${ }^{34}$, fever is currently the main diagnostic criterion, but not a suitable endpoint, for future pediatric UTI studies. Recent studies have evaluated the relapse rate of UTI after the ineffective treatment of an ESBL upper UTI in adults and children younger than 2 years old, respectively ${ }^{28,30}$. Larger-scale observational studies are needed to explore UTI relapse and selection of resistance in all age-groups after the treatment of resistant UTIs with ineffective regimens. Furthermore, potential long-term adverse events, such as renal scarring, should further be explored.

\section{CONCLUSION}

Time to defervescence and clinical failure did not differ among children receiving microbiologically effective or ineffective antibiotics for ESBL UTIs. Common beta-lactam, noncarbapenem, antibiotics may empirically be used for SBL febrile UTIs treatment, until susceptibility testing results become available. Future research should evaluate the continuation of microbiologically ineffective treatments after susceptibility results are available, as well as the possibility of long-term complications. 


\section{CONTRIBUTIONS}

$\mathrm{KV}$ and $\mathrm{RB}$ conceptualized and designed the study and performed data management and analysis. $\mathrm{KV}, \mathrm{RB}, \mathrm{LF}, \mathrm{JB}$ and $\mathrm{YS}$ contributed to the design of data collection tools. $\mathrm{KV}$ and $\mathrm{RB}$ wrote the manuscript. $\mathrm{KV}, \mathrm{RB}, \mathrm{YH}, \mathrm{JB}, \mathrm{LF}$ and $\mathrm{MS}$ interpreted the data and critically revised the manuscript for important intellectual content. KV, EA, AlB, AnB, MC, RC, MDL, JK, AMC, TP, AR, ER, TPS, AV and EV contributed data voluntarily and critically revised the manuscript for important intellectual content. All authors reviewed and approved the final manuscript before submission and agree to be accountable for all aspects of the work.

\section{ACKNOWLEDGEMENTS}

We would like to thank all colleagues who assisted to data collection: Kirkira Banou, Microbiology Department, “Aghia Sophia Children's Hospital”, Athens, Greece; Maria Bitsori, Heraklion University Hospital, University of Crete, Greece; Emmanuel Roilides, Third Department of Pediatrics, Aristotle University, Medical Faculty, School of Health Sciences, Hippokration Hospital, Thessaloniki, Greece, Thessaloniki, Greece; Livia Gargiullo, University Hospital Pediatric Department, Bambino Gesù Children's Hospital, Rome, Italy; Pablo Rojo, Hospital 12 de Octubre, Facultad de Medicina, Universidad Complutense, Madrid, Spain; Breda Zakotnik, Department of Infectious Diseases, University Medical Centre, Ljubljana, Slovenia;

Begoña Carazo Gallego, Regional University Hospital of Malaga, Spain; Fernanda Rodrigues, Hospital Pediátrico, Centro Hospitalar e Universitário de Coimbra, Coimbra, Portugal; Fiona Shaw, Alder Hey Children's NHS Foundation Trust, Liverpool, UK; Garth Dixon, Great Ormond Street Hospital for Children NHS Trust, London; Bogdan Cojocaru, Hôpital Louis-Mourier, Assistance Publique - Hôpitaux de Paris, F-92700 Colombes, France; Nora Poey, Service 
pédiatrie générale, Hôpital Robert Debré, F-75019 Paris, France; Viktoras Sutkus, Faculty of Medicine, Vilnius University, Vilnius, Lithuania

DECLARATION OF INTERESTS

JB's husband is a senior corporate counsel at Novartis International AG (Basel, Switzerland) and holds Novartis stock and stock options. AV has collaborated with Pfizer and GSK in vaccine conferences. TP is the clinical lead of a NHS diagnostic microbiology laboratory at South West London Pathology. He is on advisory boards for Roche, Pfizer, and Singulex for diagnostics. All other authors declare no competing interests.

\section{FUNDING}

No funding was received for this study.

\section{REFERENCES}

1. Centers for Disease Control and Prevention, Office of Infectious Disease Antibiotic Resistance Threats in the United States, 2013. Apr, 2013. Available at: http://Www.Cdc.Gov/Drugresistance/Threat-Report-2013. Accessed March 31, 2019.

2. World Health Organization. Antimicrobial Resistance: Global Report on Surveillance. 2014. Available at: http://Www.Who.Int/Drugresistance/Documents/Surveillancereport/En (Accessed 31 March 2019).

3. Paterson DL, Bonomo RA. Extended-Spectrum -Lactamases: a Clinical Update. Clin Microbiol Rev. 2005;18(4):657-686. 
4. Pana ZD, Zaoutis T. Treatment of extended-spectrum $\beta$-lactamase-producing

Enterobacteriaceae (ESBLs) infections: what have we learned until now? F1000Research.

2018;7:1347. doi:10.12688/f1000research.14822.1

5. Hsu AJ, Tamma PD. Treatment of Multidrug-Resistant Gram-Negative Infections in Children. Clin Infect Dis. 2014;58(10):1439-1448.

6. European Centre for Disease Prevention and Control. Surveillance of Antimicrobial Resistance in Europe - Annual Report of the European Antimicrobial Resistance Surveillance Network (EARS-Net) 2017. Stockholm: ECDC; 2018. Available from:

https://Ecdc.Europa.Eu/Sites/Portal/Files/Documents/EARS-Net-Report-2017-Update-Jan2019.Pdf (Last Accessed 21st April 2019).

7. Fedler KA, Biedenbach DJ, Jones RN. Assessment of pathogen frequency and resistance patterns among pediatric patient isolates: report from the 2004 SENTRY Antimicrobial Surveillance Program on 3 continents. Diagn Microbiol Infect Dis. 2006;56(4):427-436.

8. Morrissey I, Hackel M, Badal R, Bouchillon S, Hawser S, Biedenbach D. A Review of Ten Years of the Study for Monitoring Antimicrobial Resistance Trends (SMART) from 2002 to 2011. Pharmaceuticals. 2013;6(11):1335-1346.

9. Lukac PJ, Bonomo RA, Logan LK. Extended-Spectrum -Lactamase-Producing Enterobacteriaceae in Children: Old Foe, Emerging Threat. Clin Infect Dis. January 2015.

10. Flokas ME, Detsis M, Alevizakos M, Mylonakis E. Prevalence of ESBL-producing Enterobacteriaceae in paediatric urinary tract infections: A systematic review and meta-analysis. J Infect. 2016;73(6):547-557. 
11. MacVane SH, Tuttle LO, Nicolau DP. Impact of extended-spectrum $\beta$-lactamaseproducing organisms on clinical and economic outcomes in patients with urinary tract infection: Outcomes of ESBL-EK UTI. J Hosp Med. 2014;9(4):232-238.

12. Roberts KB; Subcommittee on Urinary Tract Infection., Steering Committee on Quality Improvement and Management. Urinary Tract Infection: clinical practice guideline for the diagnosis and management of an initial UTI in febrile infants and young children. PEDIATRICS. 2011;128(3):e749-e770.

13. National Institute for Health and Care Excellence (NICE). Urinary Tract Infection in under 16s: Diagnosis and Management. 2007. Available at: https://Www.Nice.Org.Uk/Guidance/Cg54/Evidence/Full-Guideline-Pdf-196566877. Accessed April 22, 2019.

14. World Health Organization Model List of Essential Medicines for Children, 7th List, 2019. Geneva: World Health Organization; 2019.

15. Jerardi KE, Auger KA, Shah SS, et al. Discordant antibiotic therapy and length of stay in children hospitalized for urinary tract infection. J Hosp Med. 2012;7(8):622-627.

16. European Committee on Antimicrobial Susceptibility Testing (EUCAST) Clinical breakpoints and dosing of antibiotics. Available at: http://www.eucast.org/clinical_breakpoints/. 17. Clinical and Laboratory Standards Institute, Performance standards for antimicrobial susceptibility testing. Available at: https://clsi.org/standards/products/microbiology/documents/. 18. Madhi F, Jung C, Timsit S, et al. Febrile urinary-tract infection due to extended-spectrum beta-lactamase-producing Enterobacteriaceae in children: A French prospective multicenter study. Huang Y-C, ed. PLOS ONE. 2018;13(1):e0190910. doi:10.1371/journal.pone.0190910 
19. Seo YB, Lee J, Kim YK, et al. Randomized controlled trial of piperacillin-tazobactam, cefepime and ertapenem for the treatment of urinary tract infection caused by extended-spectrum beta-lactamase-producing Escherichia coli. BMC Infect Dis. 2017;17(1):404. doi:10.1186/s12879-017-2502-x

20. Vazouras K, Basmaci R, Bielicki J, et al. Antibiotics and Cure Rates in Childhood Febrile Urinary Tract Infections in Clinical Trials: A Systematic Review and Meta-analysis. Drugs. 2018;78(15):1593-1604.

21. Zykov IN, Sundsfjord A, Småbrekke L, Samuelsen Ø. The antimicrobial activity of mecillinam, nitrofurantoin, temocillin and fosfomycin and comparative analysis of resistance patterns in a nationwide collection of ESBL-producing Escherichia coli in Norway 2010-2011. Infect Dis. 2016;48(2):99-107.

22. Koçak M, Büyükkaragöz B, Çelebi Tayfur A, et al. Causative pathogens and antibiotic resistance in children hospitalized for urinary tract infection: Urinary tract infection in children. Pediatr Int. 2016;58(6):467-471.

23. Pérez Heras I, Sanchez-Gomez JC, Beneyto-Martin P, Ruano-de-Pablo L, Losada-Pinedo B. Community-onset extended-spectrum $\beta$-lactamase producing Escherichia coli in urinary tract infections in children from 2015 to 2016: Prevalence, risk factors, and resistances. Medicine (Baltimore). 2017;96(50):e8571.

24. Vardakas KZ, Tansarli GS, Rafailidis PI, Falagas ME. Carbapenems versus alternative antibiotics for the treatment of bacteraemia due to Enterobacteriaceae producing extendedspectrum -lactamases: a systematic review and meta-analysis. J Antimicrob Chemother. 2012;67(12):2793-2803. 
25. Perez F, Bonomo RA. Can We Really Use ss-Lactam/ss-Lactam Inhibitor Combinations for the Treatment of Infections Caused by Extended-Spectrum ss-Lactamase-Producing Bacteria? Clin Infect Dis. 2012;54(2):175-177.

26. Bingen E, Bidet P, Birgy A, Sobral E, Mariani P, Cohen R. In vitro interaction between cefixime and amoxicillin-clavulanate against extended-spectrum-beta-lactamase-producing Escherichia coli causing urinary tract infection. J Clin Microbiol. 2012;50(7):2540-2541.

27. Ramos-Martínez A, Alonso-Moralejo R, Ortega-Mercader P, Sánchez-Romero I, MillánSantos I, Romero-Pizarro Y. Pronóstico de las infecciones urinarias con tratamiento antibiótico discordante. Rev Clínica Esp. 2010;210(11):545-549.

28. Kim S-H, Oh S, Huh K, et al. Inappropriate empirical antibiotic therapy does not adversely affect the clinical outcomes of patients with acute pyelonephritis caused by extendedspectrum $\beta$-lactamase-producing Enterobacteriales. Eur J Clin Microbiol Infect Dis. 2019;38(5):937-944.

29. Wang ME, Lee V, Greenhow TL, et al. Clinical Response to Discordant Therapy in ThirdGeneration Cephalosporin-Resistant UTIs. Pediatrics. 2020;145(2):e20191608. doi:10.1542/peds.2019-1608

30. Hyun HS, Kim JH, Cho MH, et al. Low relapse rate of urinary tract infections from extended-spectrum beta-lactamase-producing bacteria in young children. Pediatr Nephrol. July 2019.

31. Tratselas A, Iosifidis E, Ioannidou M, et al. Outcome of Urinary Tract Infections Caused by Extended Spectrum $\beta$-Lactamase-producing Enterobacteriaceae in Children: Pediatr Infect Dis J. 2011;30(8):709-712. 
32. Long SS, Pickering LK, Prober CG. Principles and Practice of Pediatric Infectious Diseases. 3rd Ed. New York, NY: Churchill Livingstone/ Elsevier; 2009.

33. Bhalerao S, Kadam P. Sample size calculation. Int J Ayurveda Res. 2010;1(1):55.

34. European Medicines Agency. Guideline on the evaluation of medicinal products indicated for treatment of bacterial infections. Final guidance. 2012. Available at: www.ema.europa.eu/docs/en_ GB/document_library/Scientific_guideline/2009/09/WC500003417.pdf. Accessed July 17, 2019.

35. Tratselas A, Simitsopoulou M, Giannakopoulou A, et al. Effect of Ceftriaxone on the Outcome of Murine Pyelonephritis Caused by Extended-Spectrum- $\beta$-Lactamase-Producing Escherichia coli. Antimicrob Agents Chemother. 2014;58(12):7102-7111. 
Table 1. Study Demographics

\begin{tabular}{|c|c|c|c|c|}
\hline Demographics/Characteristics & $\begin{array}{l}\text { Overall } \\
(n=142)\end{array}$ & $\begin{array}{c}\text { Initial } \\
\text { Effective } \\
(\mathrm{n}=61)^{*}\end{array}$ & $\begin{array}{c}\text { Initial } \\
\text { Ineffective } \\
(\mathbf{n}=77)^{*}\end{array}$ & p-value \\
\hline Age in years (Median, IQR) & $1.1(0.5-4.0)$ & $1.3(0.7-5.0)$ & $1.0(0.3-2.0)$ & 0.034 \\
\hline \multicolumn{5}{|l|}{ Sex } \\
\hline Male & $57(40.1)$ & $22(36.1)$ & $34(44.2)$ & \multirow[t]{2}{*}{0.385} \\
\hline Female & $85(59.9)$ & $41(63.9)$ & $43(55.8)$ & \\
\hline $\begin{array}{l}\text { Temperature in }{ }^{\circ} \mathrm{C} \text { (Median, } \\
\mathrm{IQR})\end{array}$ & $\begin{array}{c}39.0(38.4- \\
39.5)\end{array}$ & $\begin{array}{c}39.0(38.4- \\
39.5)\end{array}$ & $\begin{array}{c}39.0(38.4- \\
39.5)\end{array}$ & 0.9182 \\
\hline \multicolumn{5}{|l|}{ Type of UTI } \\
\hline Bacteraemic UTI & $7(4.9)$ & $3 / 59(5.1)$ & $3 / 74(4.1)$ & \multirow{6}{*}{0.102} \\
\hline Catheter-related UTI & $7(4.9)$ & $0 / 59(0)$ & $6 / 74(8.2)$ & \\
\hline $\begin{array}{l}\text { Vesicostomy or ureterostomy } \\
\text { related }\end{array}$ & $5(3.5)$ & $4 / 59(6.8)$ & $1 / 74(1.3)$ & \\
\hline Kidney Stone Infection & $1(0.7)$ & $0 / 59(0)$ & $1 / 74(1.3)$ & \\
\hline DMSA-confirmed UTI & $5(3.5)$ & $2 / 59(3.4)$ & $3 / 74(4.1)$ & \\
\hline None of the above & $117(82.4)$ & $52 / 59(88.1)$ & $63 / 74(85.1)$ & \\
\hline \multicolumn{5}{|l|}{ Medical History } \\
\hline $\begin{array}{l}\text { Urinary Tract (UT)- } \\
\text { abnormality }\end{array}$ & $54(38.0)$ & $31(50.8)$ & $22 / 75(29.3)$ & 0.013 \\
\hline Other comorbidity $^{* *}$ & $51(35.9)$ & $31(50.8)$ & $17(22.1)$ & $<0.001$ \\
\hline $\begin{array}{l}\text { Critically } \\
\text { ill/immunosuppressed }\end{array}$ & $18(12.7)$ & $11 / 61(18.0)$ & $5(6.5)$ & 0.058 \\
\hline
\end{tabular}




\begin{tabular}{|c|c|c|c|c|}
\hline Prophylactic antibiotics & $27(19.0)$ & $18(29.5)$ & $8 / 75(10.7)$ & 0.008 \\
\hline History of recurrent UTIs & $17(12.0)$ & $8(13.1)$ & $9(11.7)$ & 0.801 \\
\hline \multicolumn{5}{|l|}{ Pathogens } \\
\hline E. coli & $122(85.9)$ & $53(86.9)$ & $68(88.3)$ & \multirow{2}{*}{0.801} \\
\hline Non E.coli & $20(14.1)$ & $8(13.1)$ & $9(11.7)$ & \\
\hline \multicolumn{5}{|l|}{ Laboratory markers } \\
\hline $\begin{array}{l}\text { CRP serum level (mg/L) } \\
\text { (Median, IQR) }\end{array}$ & $\begin{array}{c}74.0(32.0- \\
152.0)\end{array}$ & $\begin{array}{c}46.7(14.2- \\
126.0)\end{array}$ & $\begin{array}{c}67.5(17.4- \\
152.0)\end{array}$ & 0.723 \\
\hline Abnormal creatinine & $22 / 97(22.7)$ & $11 / 41(26.8)$ & $10 / 53(18.9)$ & 0.455 \\
\hline \multicolumn{5}{|l|}{ Initial Treatment (route) } \\
\hline Parenteral & $101(71.1)$ & $46(75.4)$ & $52(67.5)$ & \multirow{3}{*}{0.500} \\
\hline Oral & $40(28.2)$ & $15(24.6)$ & $24(31.2)$ & \\
\hline Parenteral and oral & $1(0.7)$ & $0(0)$ & $1(1.3)$ & \\
\hline \multicolumn{5}{|l|}{ No. of initial antibiotic(s) prescribed } \\
\hline One antibiotic & $124(87.3)$ & $51(83.6)$ & $71(92.2)$ & \multirow{2}{*}{0.180} \\
\hline$>1$ antibiotics & $18(12.7)$ & $10(16.4)$ & $6(7.8)$ & \\
\hline \multicolumn{5}{|l|}{ Outcomes } \\
\hline $\begin{array}{l}\text { Time to defervescence in days } \\
\text { (Median, IQR) }\end{array}$ & $1.0^{* * *}(0-2.0)$ & $1.0(0-2.0)$ & $1.0(0-2.0)$ & 0.722 \\
\hline Early clinical failure & $6 / 125(4.8)$ & $2 / 59(3.4)$ & $4 / 66(6.1)$ & 0.683 \\
\hline Late clinical failure & $14 / 113(12.4)$ & $8 / 51(15.7)$ & $6 / 58(10.3)$ & 0.568 \\
\hline Microbiological failure & $12 / 43(27.9)$ & $5 / 16(31.3)$ & $7 / 27(25.9)$ & 0.737 \\
\hline Complications $^{* * * * *}$ & $5 / 137(3.6)$ & $5 / 61(8.2)$ & $0 / 72(0)$ & 0.019 \\
\hline Ward of Admission & & & & \\
\hline
\end{tabular}




\begin{tabular}{|l|c|c|c|}
\hline General Paediatrics & $57(40.1)$ & $17 / 61(27.9)$ & $39 / 77(50.7)$ \\
\hline Outpatients Clinic & $37(26.1)$ & $15 / 61(24.5)$ & $22 / 77(28.6)$ \\
\hline Paediatric Surgical/Urology & $11(7.7)$ & $7 / 61(11.5)$ & $4 / 77(5.2)$ \\
\hline Paediatric Intensive Care Unit & $8(5.6)$ & $5 / 61(8.2)$ & $2 / 77(2.6)$ \\
\hline Neonatal Intensive Care Unit & $7(4.9)$ & $3 / 61(4.9)$ & $3 / 77(3.9)$ \\
\hline Paediatric Infectious Diseases & $4(2.8)$ & $3 / 61(4.9)$ & $1 / 77(1.3)$ \\
\hline Haematology-Oncology & $2(1.4)$ & $2 / 61(3.3)$ & $0 / 77(0)$ \\
\hline Nephrology & $2(1.4)$ & $2 / 61(3.3)$ & $0 / 77(0)$ \\
\hline Other Special Wards & $14(9.9)$ & $7 / 61(11.5)$ & $6 / 77(7.7)$ \\
\hline
\end{tabular}

NOTE: Values are listed as number (percentage) or "Median, IQR" or "Mean, SD" if continuous variable. Percentages are calculated with the total number of patients mentioned in the head of each column, except when specified.

Abbreviations: UTI, urinary tract infection; $\mathrm{CRP}, \mathrm{C}$ reactive protein; $\mathrm{SD}$, standard deviation; IQR, interquartile range

* One-hundred forty-two patients were included in the study. Two patients were excluded from outcomes analysis, while two more could not be classified as effective/ineffective as the initial antibiotic given was not tested in the antibiogram. ${ }^{* *}$ cardiovascular, respiratory, gastrointestinal, neurological, endocrine, metabolic, hematological, immune, perinatal or surgical comorbidities **** on99 patients, $45(45.4 \%)$ effective and 54 (54.6\%) ineffective ${ }^{* * * * *}$ secondary sepsis, pyonephrosis, renal failure, admission to an intensive care unit and death after care was withdrawn 
Table 2. Antimicrobial resistance rates of Escherichia coli and Klebsiellasppin children with febrile ESBL UTIs.

\begin{tabular}{|l|c|c|c|c|}
\hline Species & \multicolumn{2}{|c|}{ E.coli } & \multicolumn{2}{c|}{ Klebsiellaspp } \\
\hline Antibiotic & I-R/total & $\%$ of & I-R/total & of \\
& & Resistance & & Resistance \\
\hline Co-amoxiclav & $66 / 119$ & $55.5 \%$ & $10 / 15$ & $66.7 \%$ \\
\hline Temocillin & $3 / 33$ & $9.1 \%$ & $0 / 1$ & - \\
\hline Mecillinam & $2 / 39$ & $5.1 \%$ & $0 / 1$ & - \\
\hline TZP & $19 / 100$ & $19.0 \%$ & $6 / 13$ & $46.1 \%$ \\
\hline Cefoxitin & $23 / 64$ & $35.9 \%$ & $4 / 9$ & - \\
\hline Ertapenem & $6 / 89$ & $6.7 \%$ & $0 / 9$ & - \\
\hline Imipenem & $1 / 92 *$ & $1.1 \%$ & $0 / 11$ & $0 \%$ \\
\hline Nalidixic acid & $24 / 34$ & $70.6 \%$ & $1 / 4$ & - \\
\hline Ciprofloxacin & $60 / 107$ & $56.1 \%$ & $9 / 15$ & $60.0 \%$ \\
\hline Trimethoprim & $59 / 83$ & $71.1 \%$ & $4 / 7$ & - \\
\hline Co-trimoxazole & $71 / 110$ & $64.6 \%$ & $12 / 15$ & $80.0 \%$ \\
\hline Nitrofurantoin & $3 / 101$ & $3.0 \%$ & $3 / 5$ & - \\
\hline Gentamicin & $37 / 120$ & $30.8 \%$ & $13 / 15$ & $86.7 \%$ \\
\hline Amikacin & $14 / 98$ & $14.3 \%$ & $5 / 13$ & $2 / 10$ \\
\hline Fosfomycin & $5 / 59$ & $8.5 \%$ & & \\
\hline
\end{tabular}

Abbreviations: I, intermediate; R, resistant; TZP, piperacillin-tazobactam

*intermediate resistance reported 
Table 3. Early clinical failure and time to defervescence in ESBL febrile UTIs

\begin{tabular}{|c|c|c|c|c|c|c|c|}
\hline \multirow[t]{2}{*}{$\begin{array}{l}\text { Patients' } \\
\text { Characteristics }\end{array}$} & \multicolumn{4}{|c|}{ Early clinical failure } & \multicolumn{3}{|c|}{$\begin{array}{l}\text { Time to defervescence (in } \\
\text { days) }\end{array}$} \\
\hline & Total & IET & IIT & $\begin{array}{c}\text { p- } \\
\text { value }\end{array}$ & $\begin{array}{c}\text { IET, } \\
\text { Mean } \\
\text { (SD) }\end{array}$ & $\begin{array}{l}\text { IIT,Mean } \\
\text { (SD) }\end{array}$ & $\begin{array}{c}\text { p- } \\
\text { value }\end{array}$ \\
\hline \multicolumn{8}{|l|}{ Age } \\
\hline$<29$ days & $0 / 3(0 \%)$ & $0 / 1(0 \%)$ & $0 / 2(0 \%)$ & 1.000 & - & - & - \\
\hline $\begin{array}{l}1 \text { month- } 2 \\
\text { years }\end{array}$ & $2 / 67(3.0 \%)$ & $0 / 25(0 \%)$ & $\begin{array}{c}2 / 42 \\
(4.8 \%)\end{array}$ & 0.525 & $\begin{array}{l}1.56 \\
(1.34)\end{array}$ & $1.03(0.85)$ & 0.188 \\
\hline$>2$ years & $4 / 55(7.3 \%)$ & $\begin{array}{c}2 / 33(6.1 \% \\
)\end{array}$ & $\begin{array}{l}2 / 22 \\
(9.1 \%)\end{array}$ & 1.000 & $\begin{array}{c}1.23 \\
(1.48)\end{array}$ & $1.58(1.50)$ & 0.309 \\
\hline \multicolumn{8}{|l|}{ Sex } \\
\hline Male & $2 / 55(3.6 \%)$ & $0 / 21(0 \%)$ & $\begin{array}{c}2 / 34 \\
(5.9 \%)\end{array}$ & 0.519 & $\begin{array}{l}1.13 \\
(1.02)\end{array}$ & $0.68(0.69)$ & 0.115 \\
\hline Female & $4 / 70(5.7 \%)$ & $\begin{array}{l}2 / 38 \\
(5.3 \%)\end{array}$ & $\begin{array}{l}2 / 32 \\
(6.3 \%)\end{array}$ & 1.000 & $\begin{array}{l}1.48 \\
(1.57)\end{array}$ & $1.62(1.29)$ & 0.404 \\
\hline \multicolumn{8}{|l|}{ Co-morbidities } \\
\hline UT-related & $3 / 50(6.0 \%)$ & $\begin{array}{l}1 / 31 \\
(3.2 \%)\end{array}$ & $\begin{array}{c}2 / 19 \\
(10.5 \%)\end{array}$ & 0.549 & $\begin{array}{l}1.40 \\
(1.47)\end{array}$ & $0.91(0.70)$ & 0.462 \\
\hline Non UT-related & $4 / 46(8.7 \%)$ & $\begin{array}{l}2 / 30 \\
(6.7 \%)\end{array}$ & $\begin{array}{c}2 / 16 \\
(12.5 \%)\end{array}$ & 0.602 & $\begin{array}{l}1.30 \\
(1.34)\end{array}$ & $1.24(1.25)$ & 0.936 \\
\hline Pathogens & & & & & & & \\
\hline
\end{tabular}




\begin{tabular}{|c|c|c|c|c|c|c|c|}
\hline E. coli & $\begin{array}{l}4 / 107 \\
(3.7 \%)\end{array}$ & $\begin{array}{c}1 / 50 \\
(2.0 \%)\end{array}$ & $\begin{array}{c}3 / 57 \\
(5.3 \%)\end{array}$ & 0.621 & $\begin{array}{l}1.32 \\
(1.38)\end{array}$ & $1.21(1.16)$ & 0.930 \\
\hline Non E.coli & $\begin{array}{c}2 / 18 \\
(11.1 \%)\end{array}$ & $\begin{array}{c}1 / 9 \\
(11.1 \%)\end{array}$ & $\begin{array}{c}1 / 9 \\
(11.1 \%)\end{array}$ & 1.000 & $\begin{array}{l}1.57 \\
(1.62)\end{array}$ & $1.00(1.15)$ & 0.459 \\
\hline \multicolumn{8}{|l|}{$\begin{array}{l}\text { Initial Treatment (by } \\
\text { route) }\end{array}$} \\
\hline IV/IM & $2 / 91(2.2 \%)$ & $\begin{array}{c}1 / 43 \\
(2.3 \%)\end{array}$ & $\begin{array}{c}1 / 48 \\
(2.1 \%)\end{array}$ & 1.000 & $\begin{array}{r}1.36 \\
(1.25)\end{array}$ & $1.07(0.90)$ & 0.388 \\
\hline Oral (single) & $\begin{array}{c}4 / 33 \\
(12.1 \%)\end{array}$ & $\begin{array}{c}1 / 16 \\
(6.3 \%)\end{array}$ & $\begin{array}{c}3 / 17 \\
(17.6 \%)\end{array}$ & 0.601 & $\begin{array}{l}1.33 \\
(2.34)\end{array}$ & 1.78 (1.99) & 0.460 \\
\hline \multicolumn{8}{|l|}{$\begin{array}{l}\text { Initial treatment } \\
\text { (by antibiotic class) }\end{array}$} \\
\hline Single & $\begin{array}{l}6 / 109 \\
(5.5 \%)\end{array}$ & $\begin{array}{c}2 / 49 \\
(4.1 \%)\end{array}$ & $\begin{array}{c}4 / 60(6.7 \% \\
)\end{array}$ & 0.689 & $\begin{array}{r}1.44 \\
(1.46)\end{array}$ & $1.20(1.19)$ & 0.561 \\
\hline $\begin{array}{r}\text { Aminopenicillins }+ \\
B L I^{1}\end{array}$ & $2 / 21(9.5 \%)$ & $\begin{array}{c}1 / 14 \\
(7.1 \%)\end{array}$ & $\begin{array}{c}1 / 7 \\
(14.3 \%)\end{array}$ & 1.000 & $\begin{array}{l}1.43 \\
(2.15)\end{array}$ & $1.17(1.47)$ & 0.940 \\
\hline Cephalosporins $^{2}$ & $2 / 43(4.7 \%)$ & - & $\begin{array}{c}2 / 43 \\
(4.7 \%)\end{array}$ & - & - & $1.25(1.20)$ & - \\
\hline Aminoglycosides $^{3}$ & $0 / 20(0 \%)$ & $0 / 16(0 \%)$ & $0 / 4(0 \%)$ & 1.000 & $\begin{array}{l}1.79 \\
(1.37)\end{array}$ & $1.50(1.00)$ & 0.726 \\
\hline Carbapenems $^{4}$ & $1 / 11(9.1 \%)$ & $\begin{array}{c}1 / 11 \\
(9.1 \%)\end{array}$ & - & - & $\begin{array}{l}1.36 \\
(1.29)\end{array}$ & - & - \\
\hline Other $^{5}$ & $1 / 14(7.1 \%)$ & $0 / 8(0 \%)$ & $\begin{array}{c}1 / 6 \\
(16.7 \%)\end{array}$ & 0.429 & $\begin{array}{r}0.50 \\
(0.58)\end{array}$ & $0.33(0.58)$ & 0.683 \\
\hline Combinations $^{6}$ & $0 / 16(0 \%)$ & $0 / 10$ & $0 / 6$ & 1.000 & 1.00 & $1.00(0.71)$ & 0.833 \\
\hline
\end{tabular}




\begin{tabular}{|l|l|l|l|l|l|l|l|}
\hline & & & & & $(1.12)$ & & \\
\hline
\end{tabular}

${ }^{1}$ Co-amoxiclav, piperacillin-tazobactam

${ }^{2}$ Cefotaxime, ceftriaxone, cefuroxime, cefixime, cefalexin

${ }^{3}$ Gentamicin, amikacin

${ }^{4}$ Ertapenem, imipenem/cilastatin, meropenem

${ }^{5}$ Co-trimoxazole, Nitrofurantoin, ciprofloxacin, fosfomycin, amoxicillin

${ }^{6}$ Ampicillin + cefotaxime, ampicillin + gentamicin, ampicillin + amikacin, co-

amoxiclav + amikacin, ceftriaxone + amikacin, cefoxitin + amikacin, piperacillin-

tazobactam + ciprofloxacin, piperacillin-tazobactam + amikacin, meropenem +

Vancomycin, meropenem + amikacin, meropenem + gentamicin, imipenem/cilastatin

+ amikacin, ceftriaxone + oral ofloxacin

Abbreviations: IET, Initial Effective Treatment; IIT, Initial Ineffective Treatment; BLI

- beta-lactamase inhibitor; UT - urinary tract; SD, standard deviation 


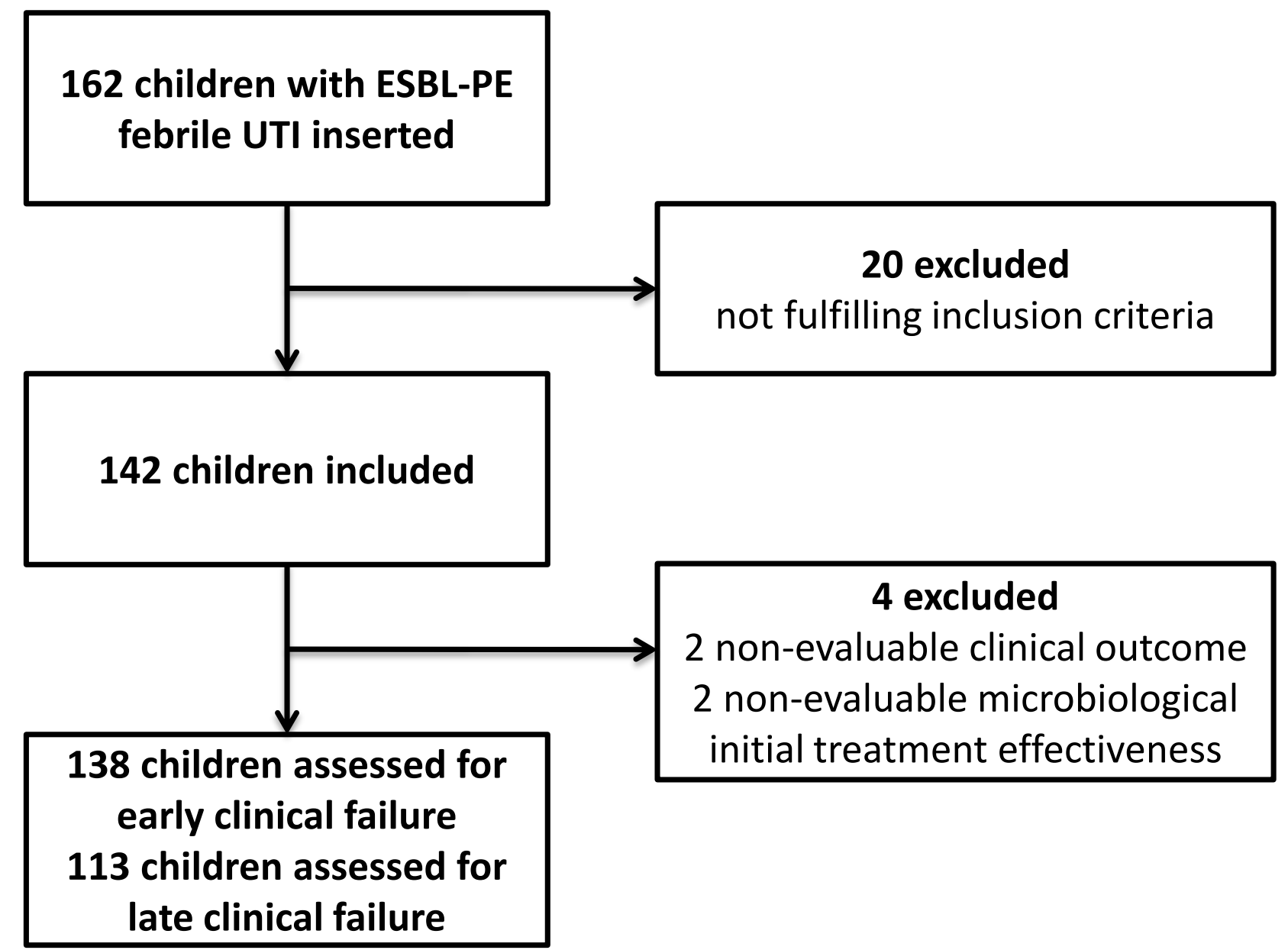

Figure 1. Formation of the cohort 


\section{Supplemental Table 1. Participating Centres and Records}

\begin{tabular}{|c|c|c|}
\hline Hospital & Country & $\begin{array}{l}\text { Records } \\
(n=142)\end{array}$ \\
\hline University Medical Centre of Ljubljana & Slovenia & 14 \\
\hline Vilnius University Children's Hospital & Lithuania & 15 \\
\hline Great Ormond Street Hospital & United Kingdom & 10 \\
\hline Alder Hey Children's Hospital & United Kingdom & 16 \\
\hline St George's University of London & United Kingdom & 5 \\
\hline Hôpital Robert Debré & France & 14 \\
\hline Hôpital Louis Mourier & France & 8 \\
\hline OspedalePediatrico Bambino Gesù & Italy & 9 \\
\hline Hippokration Hospital & Greece & 1 \\
\hline Agia Sophia Children's Hospital & Greece & 17 \\
\hline University Hospital of Herakleion & Greece & 7 \\
\hline Hospital Universitario 12 de Octubre & Spain & 10 \\
\hline $\begin{array}{c}\text { Hospital Regional Universitario de } \\
\text { Málaga }\end{array}$ & Spain & 8 \\
\hline Hospitais da Universidade de Coimbra & Portugal & 8 \\
\hline
\end{tabular}




\section{Supplemental Table 2. Initial and SwitchedRegimens for ESBL febrile UTIs}

\begin{tabular}{|c|c|c|c|c|c|}
\hline Antibiotics & $\begin{array}{c}\text { Initial } \\
\mathrm{N}=142(\%)\end{array}$ & $\begin{array}{c}\text { Switched } \\
\left(1^{\text {st }}\right) \\
\mathrm{N}=100\end{array}$ & $\begin{array}{l}\text { Switched } \\
\qquad \begin{array}{l}\left(2^{\text {nd }}\right) \\
\mathrm{N}=32\end{array}\end{array}$ & $\begin{array}{c}\text { Switched } \\
\begin{array}{c}\left(3^{\text {rd }}\right) \\
\text { N=3 }\end{array}\end{array}$ & $\begin{array}{c}\text { Switched } \\
\left(4^{\text {th }}\right) \\
N=1\end{array}$ \\
\hline Single treatments & $124(87.3)$ & $95(95.0)$ & $29(90.6)$ & - & - \\
\hline Amoxicillin & $1(0.7)$ & - & - & - & - \\
\hline Co-amoxiclav & $17(12.0)$ & $21(21.0)$ & $6(18.8)$ & - & - \\
\hline Ampicillin-sulbactam & - & $1(1.0)$ & - & - & - \\
\hline Piperacillin-tazobactam & $5(3.5)$ & $5(5.0)$ & $1(3.1)$ & - & - \\
\hline Pivmecillinam & - & $2(2.0)$ & - & - & - \\
\hline Temocillin & - & $2(2.0)$ & - & - & - \\
\hline Cefalexin & $3(2.1)$ & - & - & - & - \\
\hline Cefuroxime & $12(8.5)$ & $2(2.0)$ & - & - & - \\
\hline Cefixime & $11(7.8)$ & $2(2.0)$ & - & - & - \\
\hline Cefotaxime & $16(11.3)$ & $1(1.0)$ & - & - & - \\
\hline Ceftriaxone & $11(7.8)$ & - & - & - & - \\
\hline Ertapenem & $1(0.7)$ & $1(1.0)$ & - & - & - \\
\hline Imipenem/cilastatin & $1(0.7)$ & $2(2.0)$ & - & 1 & - \\
\hline Meropenem & $10(7.0)$ & $8(8.0)$ & $1(3.1)$ & - & - \\
\hline Gentamicin & $16(11.3)$ & $5(5.0)$ & - & - & - \\
\hline Amikacin & $7(4.9)$ & $10(10.0)$ & $1(3.1)$ & 1 & - \\
\hline Ciprofloxacin & $4(2.8)$ & $11(11.0)$ & $2(6.3)$ & - & - \\
\hline Levofloxacin & - & $1(1.0)$ & - & - & - \\
\hline Trimethoprim & - & $1(1.0)$ & $3(9.4)$ & - & - \\
\hline
\end{tabular}




\begin{tabular}{|c|c|c|c|c|c|}
\hline Co-trimoxazole & $4(2.8)$ & $9(9.0)$ & $10(31.3)$ & - & - \\
\hline Nitrofurantoin & $4(2.8)$ & $10(10.0)$ & $3(9.4)$ & 1 & - \\
\hline Fosfomycin & $1(0.7)$ & $1(1.0)$ & $2(6.3)$ & - & - \\
\hline Combinations & $18(12.7)$ & $5(5.0)$ & $3(9.4)$ & - & - \\
\hline Ampicillin + Cefotaxime & $3(2.1)$ & - & - & - & - \\
\hline Ampicillin + Gentamicin & $3(2.1)$ & - & - & - & - \\
\hline Ampicillin + Amikacin & $1(0.7)$ & $1(1.0)$ & - & - & - \\
\hline $\begin{array}{l}\text { Piperacillin-tazobactam } \\
+ \text { Ciprofloxacin }\end{array}$ & $1(0.7)$ & - & - & - & - \\
\hline $\begin{array}{l}\text { Piperacillin-tazobactam } \\
+ \text { Amikacin }\end{array}$ & $1(0.7)$ & - & - & - & - \\
\hline $\begin{array}{l}\text { Co-amoxiclav }+ \\
\text { Amikacin }\end{array}$ & $2(1.4)$ & $1(1.0)$ & - & - & - \\
\hline Ceftriaxone + Amikacin & $1(0.7)$ & $1(1.0)$ & - & - & - \\
\hline Cefoxitin + Amikacin & $1(0.7)$ & - & - & - & - \\
\hline Ceftriaxone + Ofloxacin & $1(0.7)$ & - & - & - & - \\
\hline $\begin{array}{l}\text { Meropenem + } \\
\text { Vancomycin }\end{array}$ & $1(0.7)$ & - & - & - & - \\
\hline Meropenem + Amikacin & $1(0.7)$ & - & - & - & - \\
\hline $\begin{array}{l}\text { Meropenem + } \\
\text { Gentamicin }\end{array}$ & $1(0.7)$ & $2(2.0)$ & - & - & - \\
\hline $\begin{array}{l}\text { Imipenem/cilastatin + } \\
\text { Amikacin }\end{array}$ & $1(0.7)$ & - & - & - & - \\
\hline Co-amoxiclav + & - & - & $2(6.3)$ & - & 1 \\
\hline
\end{tabular}




\begin{tabular}{|l|c|c|c|c|c|}
\hline Cefixime & & & & & \\
\hline Pivmecillinam + & - & - & $1(3.1)$ & - & - \\
Nitrofurantoin & & & & & \\
\hline
\end{tabular}


Supplemental Table 3. Characteristics and outcomes of patients treated with aninitial ineffective treatment.

\begin{tabular}{|c|c|c|c|c|c|c|}
\hline Antibiotic & $\begin{array}{c}\text { Dose } \\
\text { (mg/kg/24 } \\
\text { h) }\end{array}$ & Route & $\begin{array}{c}\text { Vulnera } \\
\text { ble }\end{array}$ & Pathogen & MIC & $\begin{array}{c}\text { EUCAST } \\
\text { breakpoin } \\
\text { ts }\end{array}$ \\
\hline \multicolumn{7}{|c|}{ Early clinical success } \\
\hline Amikacin & 15 & IV & No & E. coli & - & $>16$ \\
\hline Amoxicillin & 47 & Oral & No & E. coli & - & \\
\hline Cefalexin & - & Oral & No & E. coli & - & \\
\hline Cefalexin & - & Oral & No & E. coli & - & \\
\hline Cefalexin & 22 & Oral & $\mathrm{No}$ & E. coli & - & \\
\hline Cefixime & - & Oral & No & E. coli & - & $>1$ \\
\hline Cefixime & 8 & Oral & No & E. coli & 2 & $>1$ \\
\hline Cefixime & 8 & Oral & No & E. coli & $>64$ & $>1$ \\
\hline Cefixime & 8 & Oral & No & E. coli & - & $>1$ \\
\hline Cefotaxime & 196 & IV & No & E. coli & - & $>2$ \\
\hline Cefotaxime & 147 & IV & No & E. coli & - & $>2$ \\
\hline Cefotaxime & 200 & IV & No & E. coli & - & $>2$ \\
\hline Cefotaxime & 150 & IV & $\mathrm{No}$ & E. coli & - & $>2$ \\
\hline Cefotaxime & - & IV & No & E. coli & - & $>2$ \\
\hline Cefotaxime & - & IV & No & E. coli & - & $>2$ \\
\hline Cefotaxime & 155 & IV & No & E. coli & - & $>2$ \\
\hline Cefotaxime & 147 & IV & No & E. coli & - & $>2$ \\
\hline
\end{tabular}




\begin{tabular}{|c|c|c|c|c|c|c|}
\hline Cefotaxime & 155 & IV & No & E. coli & - & $>2$ \\
\hline Cefotaxime & - & IV & No & E. coli & - & $>2$ \\
\hline Cefotaxime & 151 & IV & $\mathrm{No}$ & E. coli & - & $>2$ \\
\hline Cefotaxime & 198 & IV & No & E. coli & - & $>2$ \\
\hline Cefotaxime & 160 & IV & $\mathrm{No}$ & E. coli & - & $>2$ \\
\hline Cefotaxime & 208 & IV & Yes & E. coli & - & $>2$ \\
\hline Cefotaxime & 200 & IV & $\mathrm{No}$ & E. coli & - & $>2$ \\
\hline Cefotaxime & 94 & IV & $\mathrm{No}$ & E. coli & - & $>2$ \\
\hline Ceftriaxone & 80.5 & IV & No & E. coli & 128 & $>2$ \\
\hline Ceftriaxone & 200 & IV & No & E. coli & 32 & $>2$ \\
\hline Ceftriaxone & 50 & IV & $\mathrm{No}$ & E. coli & - & $>2$ \\
\hline Ceftriaxone & 54 & IV & No & E. coli & - & $>2$ \\
\hline Ceftriaxone & 50 & IV & $\mathrm{No}$ & E. coli & - & $>2$ \\
\hline Ceftriaxone & 49 & IM & No & E. coli & - & $>2$ \\
\hline Ceftriaxone & 83.9 & IV & No & Klebsiellapneumonia & 128 & $>2$ \\
\hline Ceftriaxone & 50 & IV & No & E. coli & - & $>2$ \\
\hline Ceftriaxone & 78 & IV & No & $\begin{array}{c}\text { Enterobacteraeroge } \\
\text { nes }\end{array}$ & 8 & $>2$ \\
\hline Cefuroxime & 150 & IV & No & E. coli & - & \\
\hline Cefuroxime & 31 & Oral & $\mathrm{No}$ & E. coli & - & \\
\hline Cefuroxime & 31 & Oral & No & E. coli & - & \\
\hline Cefuroxime & 32 & Oral & No & E. coli & - & \\
\hline Cefuroxime & 50 & IV & No & E. coli & - & \\
\hline
\end{tabular}




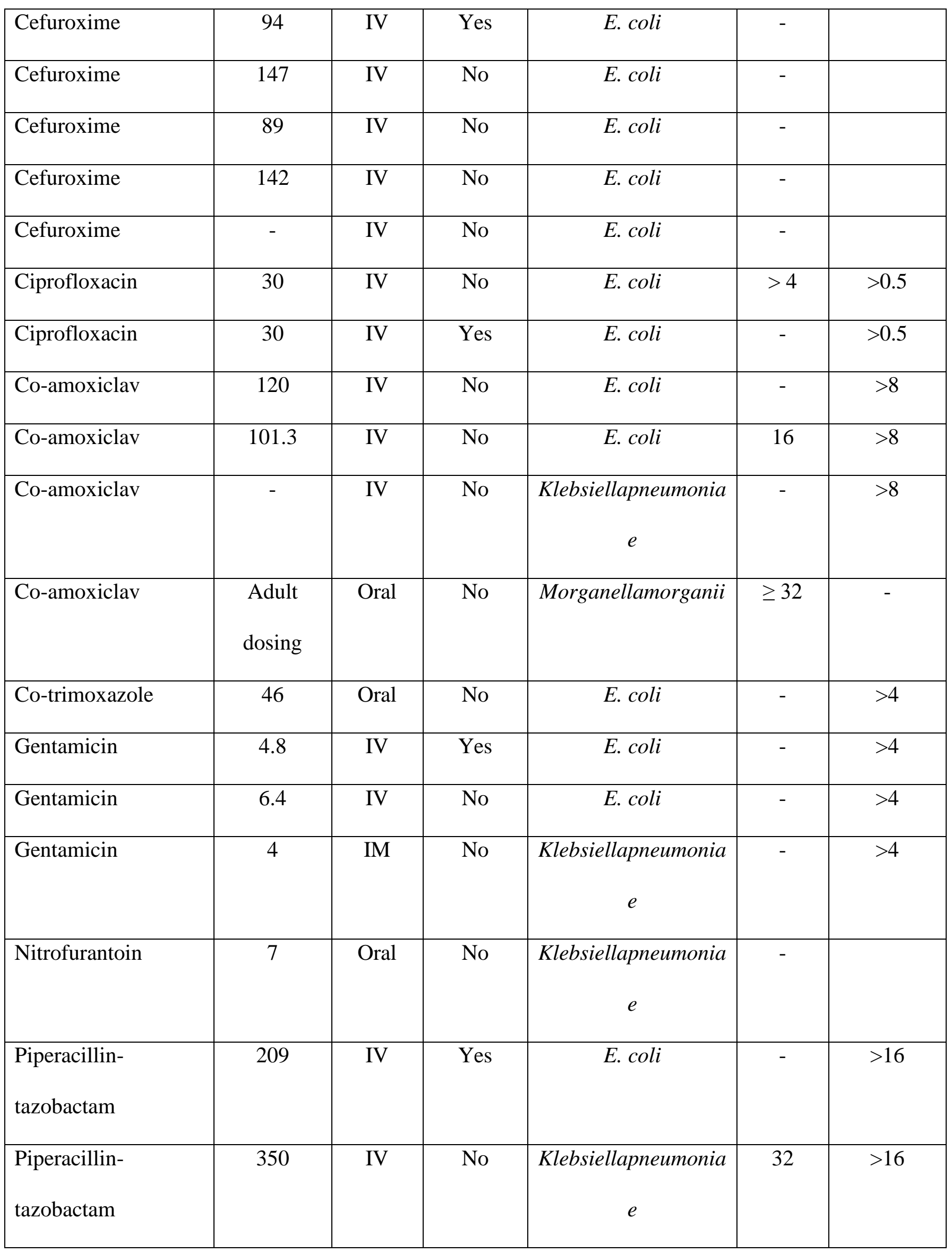




\begin{tabular}{|c|c|c|c|c|c|c|}
\hline $\begin{array}{l}\text { Ampicillin } \\
\text { \&Cefotaxime }\end{array}$ & $209 \& 209$ & IV & No & E. coli & - & $\mathrm{Na}$ \\
\hline $\begin{array}{l}\text { Ampicillin } \\
\text { \&Cefotaxime }\end{array}$ & $207 \& 207$ & IV & No & E. coli & - & $\mathrm{Na}$ \\
\hline $\begin{array}{l}\text { Ampicillin } \\
\text { \&Cefotaxime }\end{array}$ & $200 \& 150$ & IV & No & E. coli & $\begin{array}{l}(-) \& \\
64\end{array}$ & $\mathrm{Na}$ \\
\hline $\begin{array}{l}\text { Ampicillin \& } \\
\text { Gentamicin }\end{array}$ & $205 \& 5$ & IV & No & E. coli & - & $\mathrm{Na}$ \\
\hline $\begin{array}{l}\text { Ampicillin \& } \\
\text { Gentamicin }\end{array}$ & $\begin{array}{c}153.2 \& \\
3.9\end{array}$ & IV & No & Klebsiellaoxytoca & $\begin{array}{c}(-) \& \geq \\
16\end{array}$ & $\mathrm{Na}$ \\
\hline $\begin{array}{l}\text { Ceftriaxone } \\
\text { \&Ofloxacin }\end{array}$ & $\begin{array}{l}\text { Adult } \\
\text { dosing }\end{array}$ & $\begin{array}{l}\text { IV \& } \\
\text { oral }\end{array}$ & No & E. coli & - & $\mathrm{Na}$ \\
\hline \multicolumn{7}{|c|}{ Early clinical failure } \\
\hline Cefixime & 7.8 & Oral & No & E. coli & 24 & $>1$ \\
\hline Cefuroxime & 29 & Oral & No & E. coli & - & \\
\hline Co-amoxiclav & 88.2 & IV & No & $\begin{array}{c}\text { Klebsiellapneumonia } \\
e\end{array}$ & $>32$ & $>8$ \\
\hline Co-trimoxazole & 23 & Oral & No & E. coli & - & $>4$ \\
\hline
\end{tabular}

Vulnerable patients: critically ill, immunocompromised

Abbreviations: Na, not applicable 